\title{
Reflections on the Profession of College Librarianship in China
}

Mr. Wong is librarian, St. John's University, Shanghai, China.

IBRARIEs in China used to be known as $\mathcal{L}$ store-houses of knowledge where books were kept for preservation and not for use. The century-old books were meant more for the sacred custodian himself than for the wide use of the general reading public. The duty of these time-honored custodians was to keep the books in good order so that no worms would eat them or bore holes into the stitched leaves. Though a few goodsized collections, notably the imperial libraries, have existed in the history of China, hardly any of these old collections were known as libraries as we use the term today.

The story of the modern library movement in China began only a few decades ago. The seed was sown by one American librarian missionary, the late Mary Elizabeth Wood, who went to China in the I900's and was instrumental in establishing the Boone Library School connected with the Boone University in Wuchang. This was for many years the only library school in China, until the establishment of the National College of Social Education in Soochow, where a department of library science was organized a few years ago. Miss Wood was an energetic worker, and before the Boone Library School was founded she succeeded in bringing two Chinese students to the famous library school at Albany, N.Y., to be educated as her helpers in developing a school for the training of librarians and library workers for China. The libraries were to be administered on a modern principle, that of "use" rather than of "storage."

The first student sent to the United States by Miss Wood, to be trained in library science, was Samuel T. Y. Seng, who is now still faithful in his duties as the director of the Boone Library School. Thomas C. S. Hu was the second student, and he remained in the work of the Boone School, together with Mr. Seng, as its dean. For years he had also performed some useful propaganda work in giving a series of demonstrative lectures throughout the whole country on the importance of the modern library in China. Since the worst days of the recent war in China, however, Mr. Hu has left library work for a more lucrative job-that of banking, which was a necessary step to take during those lean years.

Following the footsteps of Mr. Seng and $\mathrm{Mr}$. Hu, there has been gradually a group of Chinese students coming over to the U.S. to be trained in library science. Incidentally, I must mention the name of the late H. Y. Hsü, the former librarian of St. John's University in Shanghai, who was sent over by that university in I9I4 to be educated at the library school of the New York Public Library, but unfortunately he did not live very long after he returned to China. Mr. Hsü was the third Chinese student to be educated abroad in library science. Then we have the name of Dr. T. C. Tai, for many years librarian of Tsinghua, the American indemnity college in Peking, who went to the Albany library school and later, on his second trip abroad, obtained his 
doctorate at the State University of Iowa. It would be too much to mention all the names of western trained Chinese librarians, but they represent the beginning of a stream of Chinese students going to America to be trained in this new profession. Many of these students are destined to be future library leaders of China.

The period of the real modern library movement in China, however, did not occur until the coming of Dr. Arthur E. Bostwick, an American public library administrator, then director of the St. Louis Public Library, who was invited to China in r925 to stimulate the library movement there. The National Library Association of China (C.L.A.) was then established and was subsequently followed by the organization and establishment of local library associations connected with the different provinces and cities. For many years there used to be an annual convention of the National Library Association when delegates-noted librarians and scholars interested in library work-would listen to interesting papers on library topics and participate in group discussions on library problems. The long war put a stop to these annual events. The National Association had also published a journal called the Library Science Quarterly in Chinese and also a Chinese Bulletin, which is the only thing being kept up throughout the war years. The association had also put out two small publications on the libraries in China on the occasion of its first and second ten-year anniversaries.

The second stage in the growth of a modern library movement in China could be credited to the Rockefeller Foundation in New York City, under whose auspices annual fellowships for the study of library science in this country have been granted to Chinese librarians since 1934 under the direction of the Division of Humanities. The plan was brought about through the group efforts of a few leading librarians in China, notably Dr. T. L. Yuan, director of the National Library of Peiping, Samuel T. Y. Seng, director of the Boone Library School in Wuchang, Dr. K. C. Lieu, formerly librarian of the University of $\mathrm{Nan}$ king, and other scholars. When Augustine F. Li, a Boone Library School graduate connected with the National Library of Peiping, and the author came over in 1934 as the first recipients of the library fellowship awarded by the Rockefeller Foundation, I used to remember well the words of Dr. David H. Stevens, director of the Division of Humanities, when he said to us that we were the first two Chinese scholars (really too much a compliment to us!) to be sent over to this country to study library science under the foundation's fellowship aids. But it is a regret to find that on account of the war these fellowships have not been kept up and only a few Chinese librarians have actually benefited from these aids.

The third stage in the development of a modern library movement in China could be very well credited to the United Board for Christian Colleges in China, under whose auspices Charles B. Shaw, librarian of Swarthmore College in Pennsylvania, well-known as the compiler of the "Shaw List," was invited to make a tour of investigation of the 13 Christian college libraries in China in the fall of 1947. Aside from making a study of our library situation and making definite recommendations to the United Board for the improvement of our Christian college libraries, the chief task of this good-will intellectual ambassador was to select key librarians connected with these Christian college and university libraries in China who would be granted fellowships for further study in the U.S.

Mr. Shaw arrived in China by plane on Oct. I, 1947, and left Shanghai for his return trip on Jan. I4, I948. As a result of his tour, an extensive mimeographed report 
on Christian college libraries ${ }^{1}$ in China was published by the New York office of the United Board for Christian Colleges in China. Five librarians, and also $\mathrm{Hu}$ Shaosheng, formerly of the University of Nanking and currently of the American Embassy in Nanking, who acted as Mr. Shaw's interpreter and helper on his entire trip in China, were selected for further training and study in this country. These included Miss Chiu Chu Wang, librarian of Lingnan University in Canton; Gwang-lu Den, librarian of West China Union University in Chengtu; Y. M. Chin, librarian of Fukien Christian University in Foochow; Charles Y. S. Yu, librarian of Soochow University Law School in Shanghai, and the author of this paper. All of these were awarded a year's fellowship for 1948-49, with travel expenses both ways, tuition and an adequate maintenance fee. They arrived in the U.S. in the fall. With the exception of the author, whose fellowship was granted in the nature of a "roving scholar," all the others were meant for further study and training in the well-known library schools here. These fellowships, as announced by the United Board, were made available from funds contributed by the Harvard-Yenching Institute.

The life of the college librarian in China, however, has been somewhat unfortunate. As Mr. Shaw has said in his report, the librarians are in a worse economic plight than are the professors. No wonder then that many trained librarians change their profession upon their return to China or after spending only a few years in actual library work. The fact is that the librarian who works a 40 -hour week is physically unable to take a second job, even if he is a conscientious and persevering worker, since his task will never be done. $\mathrm{He}$ has to be the first one to examine every book of the

1 Shaw, Charles B. The Libraries of The Christian Colleges in China: A Report of a Survey made in 1947-48. New York, 1948. (Mimeographed.) year's acquisitions of the library, many of which are old books, both Chinese and western, and may be the most unhygienic kind of books which a library can get. It is more and more a firm belief now that Chinese college librarians, aside from being well versed in both Chinese and English, have to be men of strong physique and healthy resistance, and they should be out in the sun more. Unfortunately, not all of the librarians in China can change their profession so easily, especially one who has spent almost his lifetime in it.

The work of the college librarian in a medium-sized library is not easy, more especially in China where the clientele of the library is not so library-minded as the library users in America. The library reading room might be easily converted into a tea-house rather than a place for quiet reading. The habits of the students have to be developed and adapted to the quiet atmosphere of the library. The cooperation of the faculty in the use of the library has to be sought.

The work of the college or university librarian is administrative, technical and instructional. As an administrator he has many things to plan which would easily put him in line with the deans of the college or university, as are college librarians in this country. As a technician he has to know all the rules of classification and cataloging, loan work and general reference. As an instructional officer he has to give the needed kind of indirect teaching to the students to supplement the work of the teacher in the classroom.

In a way, the position of the university librarian in China is almost equivalent to the director of libraries in a university in the United States. Yet he has to do all the work pertaining to his library, perhaps ranging from the work of the janitor to that of the highest duties of an executive. $\mathrm{He}$ is expected to arrive first in his office in the 
morning and to leave last in the afternoon. While his assistants could take some time off during the day because of their noon, late afternoon or evening duties, the librarian is supposed to be in all the time. His assistants could leave the office as soon as the bell strikes, no matter whether the work of the library is busy or not, but the librarian has to go on finishing up the day's work. When the assistants could have their turn off during holidays and vacations, the librarian is expected to be in his office during all holidays. Evidently he is the first one to be noticed when he is not in. For any need or emergency during the hours when the library is closed, he is also the first one to be approached. Moreover, he has other responsibilities of the library to look after, for example, the general order and care of the building, even though there are janitors.

On the other hand there is the question of a larger concern which confronts the Chinese college or university librarian. This is the question of his academic status and faculty rank in the educational set-up of the institution. While the author was working for his Master's degree in the School of Library Service at Columbia University from 1935-36, he made a special study of the college library personnel in China. It was a surprise to find a great variety of discrepancies in the matter of rank and status for the Chinese college or university librarian then. Some were given the rank of a full professor, others were only treated as instructors, while many others were not given faculty rank at all. A few were given the rank of professor, but no actual privileges that go with the rank of professors were given to them. Obviously this shows that librarianship in China has not reached a position of great standing and influence in the whole academic organization.

Moreover, there is the traditional jealousy between an instructional member of the university faculty and the librarian, which should be removed some day. The timehonored conception that the work of the librarian (I mean the head librarian) is easier than that of a teaching member is not correct in the true sense of the statement if the Chinese college or university librarian is to be a librarian or chief executive of the library who really works. It is no longer equally correct to say that the work of the teacher is more difficult than that of the head librarian if the teacher only teaches as a matter of mere drill all the years over. This jealousy seems to be such that it could never be lifted, for an ambitious young teacher could, after years of teaching, be promoted from instructor to lecturer, then from lecturer to assistant professor, and after a few more years, from assistant professor to probably associate professor or full professor, but the librarian in a Chinese college or university could ordinarily have never climbed up the ladder in similar fashion. Even if one is appointed librarian of the college or university he serves, and is entitled to the rank of professor, he would never be treated and respected as such.

All this is rather disappointing for the future profession of college librarianship in China. It would suggest having all college librarians in China hold a concurrent duty on the teaching staff, but even then, not all librarians can teach, just as all teachers cannot do the librarian's work. Some may be very good men of words, but may not be efficient men of action, and some may be efficient men of action, but may not be men of words to do classroom teaching. But if the status of the college or university librarian in China, on account of the important position it carries, could be raised, then the profession of college librarianship in China would be as attractive as that of teaching. It is the sincere hope of the author, who has spent long years of university library work in China, to see the day when 
the college or university librarian in China, with all his training, experience, and interest in the work, can be given a better academic status and a more recognized faculty ranking in the institution which he serves. It is then, and only then, that the ambitious Chinese librarians who have received proper training in the West will not be easily lured to a more tempting field other than the profession in which he was trained. I honestly believe that the profession of college librarianship, in spite of all its shortcomings and low attraction, should be one of the most wholesome and decent professions in China. On the other hand, while we must have enough faith and interest in the work we are doing, we should, at the same time, be given enough respect in the position we hold to keep us from being enticed to other walks of life which may be more lucrative. I agree with a $W$ isconsin librarian, who went to China years ago, that the term "librarian" should not be abused, and I hope that many will be attracted to this young profession in China despite its being a little bit undervalued at present.

\section{Research Libraries of Scandinavia}

\section{(Continued from page 343)}

is especially noticeable. The personnel of the bookstores appeared to be thoroughly acquainted with their wares, and very professional in manner.

One of the finest bookstores visited was the Akademiska Bokhandel in Helsinki, the largest in all of northern Europe. The store sells nothing but books, and employs a staff of over 200. When one considers that Helsinki has a population of hardly more than 300,000 , and that there are literally dozens of bookstores in the city, Akademiska Bokhandel is little less than amazing. The manager of the concern was justly proud of his establishment, which is patronized widely by libraries and individuals throughout Scandinavia, and stated that he could sell many times the present amount of British and American books if he were allotted the necessary pound and dollar exchange with which to import them. The postwar period has seen a sizeable increase in the book trade, inasmuch as people have little else which they are able to buy, and also because of a growing interest in what has happened and is happening throughout the other parts of the world.

There is a great deal of interest in British and American publications in all the Scan- dinavian countries, and the purchase of such English language books by the libraries and bookstores is limited almost solely by the foreign currency exchange made available to them by their respective governments. The manager of one of the better bookstores in Oslo stated that prior to the war his annual sales of American publications, both popular and scholarly, exceeded $\$ 50,000$. At the present time English language items disappear from the shelves almost as rapidly as they are secured for sale, with current government regulations limiting importations almost entirely to scientific fields. Were it not for these necessary restrictions, the postwar scale of books in English would far outdistance the earlier annual figure.

To recall again in writing some of the impressions of 10 weeks among the libraries and librarians of Scandinavia is to kindle nostalgia. It is to be hoped that these few observations will at least have given impetus to a few readers' interest in an area of European librarianship perhaps not so widely known among the profession in this country. To present an authoritative account would require considerably more than an article of this length based upon a visit of such short duration. 